\title{
Studi Kasus Kehamilan Dengan Risiko Tinggi
}

\author{
Linda Ratna Sari ${ }^{1 *}$, Fitriyani $^{2}$ \\ ${ }^{1,2}$ Proagram Studi Diploma Tiga Kebidanan, Universitas Muhammadiyah Pekajangan \\ Pekalongan, Indonesia \\ *email: yoolinda07@gmail.com
}

\begin{abstract}
Maternal mortality rate (MMR) and infant mortality rate (IMR) are determinants and benchmarks for the success of health service delivery. In 2019 Indonesia's Maternal Mortality Rate (MMR) is still high, at 305 per 100,000 live births. The purpose of this case study is to provide midwifery care during pregnancy to high-risk mothers aged over 35 years and mild anemia to minimize complications that will occur. The method of this case study is to provide midwifery care to pregnant women with high risk in the form of exposure to the subject of one client who experiences a high risk of pregnancy who will be given care during pregnancy. The results of this case study are given care to reduce the complaints felt by the client and carry out early detection to reduce the occurrence of complications. The conclusion of this case study is midwifery care for Ny. $\mathrm{N}$ during pregnancy in Pekalongan has been carried out on high-risk patients aged more than 35 years and mild anemia according to the needs and authority of the midwife so that it does not cause any complications. For this reason, midwives need to provide care as a form of early detection to reduce the incidence of complications
\end{abstract}

Key Word: Maternity care, pregnant, high risk

\begin{abstract}
Abstrak
Angka kematian ibu (AKI) dan angka kematian bayi (AKB) menjadi penentu dan tolak ukur keberhasilan penyelenggaraan pelayanan kesehatan. Pada tahun 2019 Angka Kematian Ibu (AKI) Indonesia masih tetap tinggi, yaitu 305 per 100.000 kelahiran hidup. Tujuan dari studi kasus ini adalah memberikan asuhan kebidanan selama masa kehamilan pada ibu dengan risiko tinggi usia diatas 35 tahun dan anemia ringan untuk meminimalkan komplikasi yang akan terjadi. Metode studi kasus ini adalah dengan pemberian asuhan kebidanan pada ibu hamil dengan risiko tinggi berupa pemaparan dengan subyek satu klien yang mengalami risiko tinggi dalam kehamilanya yang akan diberikan asuhan selama masa kehamilan. Hasil studi kasus ini diberikan asuhan untuk mengurangi keluhan yang dirasakan klien serta melakukan deteksi dini untuk mengurangi terjadinya komplikasi. Simpulan studi kasus ini adalah asuhan kebidanan pada Ny. N selama masa kehamilan Pekalongan sudah dilakukan pada pasien yang mengalami risiko tinggi usia lebih dari 35 tahun dan anemia ringan sesuai kebutuhan dan kewenangan bidan sehingga tidak menimbulkan komplikasi apapun. Untuk itu bidan perlu melakukan asuhan sebagai bentuk deteksi dini untuk mengurangi timbulnya komplikasi
\end{abstract}

Kata kunci: asuhan kebidanan, ibu hamil, risiko tinggi

\section{Pendahuluan}

Angka kematian ibu (AKI) dan angka kematian bayi (AKB) menjadi penentu dan tolak ukur keberhasilan penyelenggaraan pelayanan kesehatan. Menurut Ketua Komite Ilmiah International Conference on Indonesia Family Planning and Reproductive Health (ICIFPRH), hingga tahun 2019 Angka Kematian Ibu (AKI) Indonesia masih tetap tinggi, yaitu 305 per 100.000 kelahiran hidup. Namun data ini masih jauh dari target sustainable development goal's (SDG's) tahun 2030 yaitu dengan menurunkan AKI sebanyak 70 per 100 Tingginya AKI merupakan salah satu tantangan yang harus 


\section{Prosiding Seminar Nasional Kesehatan \\ Lembaga Penelitian dan Pengabdian Masyarakat Universitas Muhammadiyah Pekajangan Pekalongan}

dihadapi Indonesia sehingga menjadi salah satu komitmen prioritas nasional, yaitu mengurangi kematian ibu saat hamil dan melahirkan (Podungge, 2020).

Faktor yang menyebabkan kematian ibu secara garis besar dapat dikelompokan menjadi penyebab langsung dan penyebab tidak langsung. Determinan dekat yang berhubungan langsung dengan kematian ibu merupakan gangguan obstetrik seperti perdarahan, preeclampsia/eklampsia, dan infeksi atau penyakit yang diderita ibu sebelum atau selama kehamilan yang dapat memperburuk kondisi kehamilan seperti penyakit jantung, malaria, tuberkulosis, ginjal dan acquired immunodeficiency syndrome. Determinan dekat secara langsung dipengaruhi determinan antara yang berhubungan dengan faktor kesehatan, seperti status kesehatan ibu, status kesehatan reproduksi, akses terhadap pelayanan kesehatan dan perilaku pengguna fasilitas pelayanan kesehatan (Susiana, 2019).

Penyebab tidak langsung pada kematian ibu antara lain faktor yang memperberat keadaan ibu hamil seperti yang disebabkan karena risiko tinggi. Kehamilan risiko tinggi ditemukan pada ibu hamil yang memiliki masalah usia, paritas dan jarak kehamilan atau yang dikenal dengan empat terlalu yaitu terlalu tua (usia $<35$ tahun), terlalu muda (usia >20 tahun), terlalu banyak ( $>4$ anak) dan terlalu dekat (jarak kehamilan $<2$ tahun) serta dari faktor kondisi sosial pendidikan dan pekerjaan), keikutsertaan KB serta keinginan untuk hamil status ekonomi, dan kunjungan antenatal (Marceliya,2018).

Kehamilan pada usia lebih dari 35 tahun menyebabkan risiko timbulnya kombinasi antara penyakit usia tua dan kehamilan tersebut yang menyebabkan risiko meninggal atau cacat pada bayi dan ibu hamil menjadi bertambah tinggi. Terjadinya komplikasi pada kehamilan pada ibu hamil primi gravida, $65 \%$ diantaranya terjadi usia antara $16-$ 19 tahun. Selain itu juga banyak yang terjadi pada usia $>35$ tahun yaitu sebanyak 35 \%. Dari komplikasi tersebut $30 \%$ dengan hiperemisis gravidarum, 22, $5 \%$ dengan abortus, $17,5 \%$ dengan pre eklampsi ringan, $16,25 \%$ orang anemia, 7,5\% orang perdarahan ante partum, 3,75 \% orang dengan ketuban pecah dini, 2,5\% orang dengan pre eklampsi berat (Sutarmi, 2013).

Berdasarkan hasil penelitian Salmariantiti (2012) dalam penelitian Astriana (2017) bahwa umur ibu sangat berpengaruh terhadap kejadian anemia saat kehamilan. Hasil penelitin menunjukan ada hubungan antara umur ibu dengan kejadian anemia yaitu nilai prevalence ratio $(P R)=1,8$ dan $95 \%$ CI antara 1,07-3,28 yang artinya ibu hamil pada umur berisiko berpeluang mendapatkan anemia 1,8 kali dibandingkan dengan ibu hamil pada umur tidak berisiko yaitu 20-35 tahun (Astriana, 2017).

Anemia dapat menyebabkan peningkatan resiko komplikasi pada saat kehamilan, persalinan, dan nifas. Menurut Manuaba 2012 komplikasi anemia dalam kehamilan dapat terjadi abortus, persalinan prematur hambatan tumbuh kembang janin dalam Rahim, mudah terjadi infeksi, ancaman dekompensasi kordis ( $\mathrm{Hb}<7 \mathrm{~g} \%$ ), mola hidatidosa, resiko infeksi, hiperemesis gravidarum, perdarahan antepartum, ketuban pecah dini, meningkatnya insiden preeklamsi dan sepsis serta peningkatan curah jantung dan peningkatan beban kerja pemompaan jantung (Fatkhiya, 2018).

Berdasarkan data dari Dinas Kesehatan Kabupaten Pekalongan bulan Desember Tahun 2019 di Kabupaten Pekalongan ada sekitar 4.657 ibu hamil dengan risiko tinggi 


\section{Prosiding Seminar Nasional Kesehatan \\ Lembaga Penelitian dan Pengabdian Masyarakat Universitas Muhammadiyah Pekajangan Pekalongan}

sebanyak ibu hamil Di Pekalongan yaitu sekitar 26,23 \% ibu hamil Di Pekalongan, Sedangkan ibu hamil dengan anemia di Kabupaten Pekalongan sekitar 2500 dari 17753 sasaran ibu hamil atau sekitar $14 \%$ ibu hamil di Pekalongan mengalami anemia. Hal ini tentu menjadi masalah yang mengganggu kesehatan ibu maupun janin yang dikandungnya sehigga perlu penanganan agar tidak terjadi resiko komplikasi pada ibu maupun pada janin.

Berdasarkan Data Puskesmas Bojong Kabupaten Pekalongan terdapat sekitar 192 ibu hamil dengan risiko tinggi yaitu sebanyak $17 \%$ ibu hamil di Kecamatan Bojong dengan risiko tinggi. Sedangkan ibu hamil dengan anemia di Puskesmas Bojong sekitar 21 ibu hamil dengan anemia yaitu sebanyak $2 \%$ ibu hamil di Kecamatan Bojong mengalami anemia.

Dari latar belakang diatas penulis tertarik untuk mengambil kasus $\mathrm{Ny} . \mathrm{N}$ dengan risiko tinggi usia dan anemia ringan untuk diberikan asuhan sesuai dengan kebutuhan pasien agar dapat ditangani lebih dini sehingga resiko komplikasi yang terjadi bisa diminimalkan.

\section{Metode}

Metode studi kasus ini berupa paparan hasil penerapan proses asuhan kebidanan kepada klien secara ideal sesuai dengan teori dan berisi pembahasan atas kesenjangan yang terjadi di lapangan sesuai dengan 7 langkah manajemen Varney pada Ny. N sebagai subyek yang memiliki risiko tinggi .Penyusunan studi kasus ini dilaksanakan melalui Studi Pendahuluan yang bertujuan untuk memperoleh data primer. Yang dimaksud dengan data primer adalah yang diperoleh mahasiswa secara langsung dari sumber data, baik melalui pengamatan (observation), wawancara (Interview), maupun hasil pengukuran langsung lainnya (Agrippina, 2017).

Metode pengumpulan data yang digunakan meliputi Wawancara (hasil anamnesa) berisi tentang identitas pasien, keluhan utama, riwayat penyakit sekarang, riwayat penyakit dahulu, riwayat penyakit keluarga, pengkajian 11 pola Gordon. Sumber data diperoleh dari pasien,keluarga, dan bidan. Kemudian hasil wawancara atau anamnesis ditulis dibuku catatan kemudian di salin diformat pengkajian pasien, Observasi dan pemeriksaan fisik dengan pendekatan IPPA (inspeksi, palpasi, perkusi, dan auskultasi) secara head to toe. Kemudian hasil observasi ditulis dalam buku catatan yang selanjutnya disalin dalam lembar pengkajian pasien, Studi dokumentasi yaitu memperoleh data dari hasil pemeriksaan diagnostik dan rekam medis pasien. Prosedur analisa data yang digunakan adalah dengan menarasikan data yang diperoleh selama wawancara dan observasi untuk diinterpretasikan peneliti dibandingkan dengan teori yang ada guna memberikan rekomendasi dalam intervvensi yang di berikan.

\section{Hasil dan pembahasan}

Hasil dari studi kasus ini adalah sebagai berikut : Kunjungan pertama dilakukan pada tanggal 30 november 2020. Data subjektif ibu mengalami keluhan sering berkemih kurang lebih 8 kali sehari, sejak kehamilan, dan sering mengalami kontraksi palsu tidak nyeri sudah beberapa hari hilang bila dibawa istirahat. HPHT 17 April 2020. Data obyektif Tanda-tanda vital dalam batas normal. BB sebelum hamil $42 \mathrm{~kg}, \mathrm{BB}$ sekarang $67 \mathrm{~kg}$, LILA $28 \mathrm{~cm}$, TB $155 \mathrm{~cm}$. Abdomen : TFU pertengahan pusat dengan 


\section{Prosiding Seminar Nasional Kesehatan \\ Lembaga Penelitian dan Pengabdian Masyarakat Universitas Muhammadiyah Pekajangan Pekalongan}

px $(26 \mathrm{~cm})$. Bagian fundus teraba bokong. Bagian kanan teraba punggung. Bagian kiri teraba ekstremitas. Bagian terendah janin teraba kepala, dan masih dapat digoyangkan (belum masuk PAP). TBJ (TFU - 12) x 155= (26 - 12) x $155=2170$ gram. DJJ : 135x/menit. Pemeriksaan penunjang HB $11 \mathrm{~g} \%$, pemeriksaan urine reduksi dan protein urine negatif.

Diagnosa dari pemeriksaan kehamilan kunjungan pertama Ny. $\mathrm{N}$ umur 36 tahun G4P3A0 usia kehamilan 32 minggu, janin tunggal hidup intra uterin puka, preskep belum masuk PAP.

Penatalaksanaan yang diberikan yaitu menginformasikan hasil pemeriksaan, memberi ibu dukungan dan motifasi, Menginformasikan ibu mengenai ketidaknyamanan trimester 3 terutama pada keluhan ibu mengenai sering berkemih dan kontraksi palsu, Menginformasikan ibu mengenai pendidikan kesehatan mengenai risiko tinggi kehamilan, serta menganjurkan ibu mengurangi minum dimalam hari. An menganjurkan ibu periksa rutin sebagai upaya deteksi dini karena ibu tergolong risiko tinggi

Kunjungan ke dua dilakukan pada tanggal 14 Desember 2020, Di dapatkan data subyektif sebagai berikut Ibu sudah mengurangi minum pada malam hari sehingga berkurang frekuensi buang air kecil pada malam hari tetapi masih sering buang air kecil, Ibu mengatakan masih sering mengalami kenceng-kenceng saat janin bergerak. Kencang yang dirasakan hanya sebentar dan diatasi dengan istirahat rileks sebentar, Ibu mengatakan masih merasa cemas jika nanti harus bersalin dirumah sakit lagi, dan anaknya sedang tidak enak badan sering rewel sehingga ibu sering kelelahan dan kurang istirahat. Ibu mengatakan merasa cemas dengan kondisi anaknya, dan Ibu mengatakan sudah pernah mengetahui mengenai perawatan payudara tetapi lupa.

Data obyektif Tanda-tanda vital dalam batas normal. BB sekarang $68 \mathrm{~kg}$, Abdomen : TFU pertengahan pusat dengan px $(28 \mathrm{~cm})$. Bagian fundus teraba bokong. Bagian kanan teraba punggung. Bagian kiri teraba ekstremitas. Bagian terendah janin teraba kepala, dan masih dapat digoyangkan (belum masuk PAP). TBJ (TFU - 12) $\times 155=(28$ - 12) x 155 = 2400 gram. DJJ : 135x/menit.

Diagnosa dari pemeriksaan kehamilan kunjungan pertama Ny. $\mathrm{N}$ umur 36 tahun G4P3A0 usia kehamilan 34 minggu, janin tunggal hidup intra uterin puka, preskep belum masuk PAP.

Penatalaksanaan yang diberikan yaitu menginformasikan hasil pemeriksaan, memberi anjuran kepada ibu untuk memenuhi kebutuhan istirahat 7-8 jam perhari dan tidur siang 1-2 jam. Dalam menjaga anak bisa bergantian dengan suami, memberi ibu dukungan dan semangat dalam menjalani kehamilan ini dan dalam merawat anaknya, Menginformasikan kepada ibu mengenai pendidikan kesehatan perawatan payudara. Dan menganjurkan ibu untuk melakukan USG karena ibu belum pernah pemeriksaan USG sebelumnya.

Pada kunjungan ketiga ini dilakukan pada tanggal 28 Desember 2020. Dari kunjungan ini didapatkan data subyektif sebagai berikut Ibu mengatakan masih sering buang air kecil, Ibu mengatakan anaknya masih sering rewel sehingga ibu sering kurang istirahat, Ibu mengatakan juga masih sering mengalami kencang- kencang ketika lelah. Ibu mengatasinya dengan duduk rileks agar tidak sakit 


\section{Prosiding Seminar Nasional Kesehatan \\ Lembaga Penelitian dan Pengabdian Masyarakat Universitas Muhammadiyah Pekajangan Pekalongan}

Di dapatkan data obyektif Tanda-tanda vital dalam batas normal. BB sekarang 68 $\mathrm{kg}$, Abdomen : TFU 3jari bawah px $(30 \mathrm{~cm})$. Bagian fundus teraba bokong. Bagian kanan teraba punggung. Bagian kiri teraba ekstremitas. Bagian terendah janin teraba kepala, dan masih dapat digoyangkan (belum masuk PAP). TBJ (TFU - 12) x 155=(30 - 12) x 155 = 2790 gram. DJJ : 140x/menit. Hasil USG Hamil :tunggal, Hidup, Letak : kepala, Plasenta : di segmen atas Rahim, Air ketuban : cukup, DJJ +, TBJ : 2732 gram, Jenis kelamin : laki-laki.

Diagnosa dari pemeriksaan kehamilan kunjungan pertama Ny. $\mathrm{N}$ umur 36 tahun G4P3A0 usia kehamilan 36 minggu, janin tunggal hidup intra uterin puka, preskep belum masuk PAP.

Penatalaksanaan yang diberikan yaitu menginformasikan hasil pemeriksaan, menganjurkan ibu tetap memenuhi kebutuhan istirahat tidur 7-8 jam perhari dan tidur siang 1-2 jam, menganjurkan ibu untuk mengurangi makanan manis agar tidak terjadi lonjakan penambahan berat badan dan menguragi risiko bayi besar mengingat taksiran berat janin sudah cukup besar,memberitahu ibu persiapan persalinan, memberi ibu pendidikan kesehatan mengenai tanda bahaya kehamilan. Menganjurkan ibu tetap periksa rutin

Pada kunjungan berikutnya dilakukan pada tanggal 4 januari 2021. Data subyektif didapatkan yaitu Ibu mengatakan masih sering buang air kecil tetapi tidak mengganggu istirahat. Ibu merasa sering merasa lelah. Ibu mengatakan semakin sering merasakan kenceng-kenceng apabila dibawa beraktifitas. Ibu mengatasinya dengan duduk rileks dan mengurangi berjalan jauh, Ibu mengatakan anaknya masih sering rewel pada malam hari sehingga mengganggu istirahat ibu.

Data obyektif Tanda-tanda vital dalam batas normal. BB sekarang $69 \mathrm{~kg}$, Abdomen : TFU 3jari dibawah px $(31 \mathrm{~cm})$. Bagian fundus teraba bokong. Bagian kanan teraba punggung. Bagian kiri teraba ekstremitas. Bagian terendah janin teraba kepala, dan masih dapat digoyangkan (belum masuk PAP). TBJ (TFU - 12) x 155=(28 - 12) x 155 = 2945 gram. DJJ : 133x/menit, hasil pemeriksaan $\mathrm{Hb}$ kedua 9,7 gr \% (anemia ringan)

Diagnosa dari pemeriksaan kehamilan kunjungan pertama Ny. $\mathrm{N}$ umur 36 tahun G4P3A0 usia kehamilan 37 minggu, janin tunggal hidup intra uterin puka, preskep belum masuk PAP.

Penatalaksanaan yang diberikan yaitu menginformasikan hasil pemeriksaan, memberi ibu pendidikan kesehatan mengenai anemia, menganjurkan ibu konsumsi tablet tambah darah 1 kali sehari diminum saat malam hari sebelum tidur untuk mengurangi efek mual, menganjurkan ibu memenuhi kebutuhan nutrisi dan cairan teutama yang banyak mengandung zat besi seperti hati, daging, ikan dan lain-lain, menganjurkan ibu tetap memenuhi kebutuhan istirahat, tidur cukup dan mngurangi aktifitas berat dan tetap periksa rutin ke tenaga kesehatan.

Pada kunjungan terakhir ini didapatkan data subyektif meliputi Ibu mengatakan sudah mengkonsumsi tablet tambah darah secara rutin tetapi ibu masih merasa lemes dan lesuh, Ibu mengatakan masih sering BAK sehari kurang lebih 6 kali tetapi tidak mengganggu istirahat ibu, Ibu mengatakan masih merasa kenceng-kenceng. Apabila kencen ibu istirahat duduk dan atur nafas, dan Ibu mengatakan merasa cemas lagi dengan proses persalinanya nanti apabila harus dibawa kerumah sakit lagi, 


\section{Prosiding Seminar Nasional Kesehatan $\mathbf{2 0 2 1}$ \\ Lembaga Penelitian dan Pengabdian Masyarakat Universitas Muhammadiyah Pekajangan Pekalongan}

Data obyektif Tanda-tanda vital dalam batas normal. BB sekarang $70 \mathrm{~kg}$, Abdomen : TFU sejari dibawah px $(32 \mathrm{~cm})$. Bagian fundus teraba bokong. Bagian kanan teraba punggung. Bagian kiri teraba ekstremitas. Bagian terendah janin teraba kepala, dan masih dapat digoyangkan (belum masuk PAP). TBJ (TFU - 11) x 155=(32 - 11) x 155 $=3255$ gram. DJJ : 133x/menit.

Diagnosa dari pemeriksaan kehamilan kunjungan pertama Ny. $\mathrm{N}$ umur 36 tahun G4P3A0 usia kehamilan 34 minggu, janin tunggal hidup intra uterin puka, preskep sudah masuk PAP.

Penatalaksanaan yang diberikan yaitu menginformasikan hasil pemeriksaan, menganjurkan ibu memenuhi kebutuhan nutrisi dan cairan yang banyak mengandung zat besi seperti hati, daging, ikan dan lain-lain untuk mendukung ibu dalam menaikan $\mathrm{Hb}$ ibu, memberi pendidikan kesehatan mengenai ASI eksklusif untuk persiapan menyusui, menganjurkan ibu untuk rutin konsumsi tablet tambah darah apalagi ibu agar kadar $\mathrm{Hb}$ cepat naik untuk persiapan persalinan, serta tetap memenui kebutuhan istirahat ibu dan mengurangi aktifitas berat. Menganjurkan ibu pula tetap rutin periksa ke tenaga kesehatan.

Pembahasan dari hasil studi kasus ini adalah Berdasarkan hasil pengkajian awal pada tanggal 30 November 2020 pukul 15.00 WIB ditegakan diagnosa Ny. N 36 tahun G4P3A0 hamil 32 minggu janin tunggal, hidup, intra uterine, puka, preskep, belum masuk panggul, ibu mengalami salah satu factor risiko dalam kehamilan yaitu usia ibu lebih dari 35 tahun. Pada data subyektif didapatkan usia ibu 36 tahun yang mana menurut teori hamil diusia tersebut termasuk kedalam kehamilan risiko tinggi. Ibu hamil dengan usia lebih dari 35 tahun beresiko lebih tinggi mengalami komplikasi saat kehamilan dan persalinan.

Hal ini sejalan dengan hasil penelitian Sutarmi pada tahun 2013 bahwa terbukti ada hubungan yang signifikan antara usia ibu dengan komplikasi kehamilan dan dapat dilihat daei nilai p.Value 0.000 . sedangkan odd rasio/ factor resiko (OR) yaitu 4,363 artinya ibu hamil yang memiliki usia yang berisiko mempunyai risiko 4,363 kali mengalami komplikasi kehamilan.

Pada kunjungan tanggal 4 januari 2021 dilihat dari data subyektif ibu sering merasa lelah dan data obyektif menunjukan kadar $\mathrm{Hb}$ ibu adalah 9,7 gr\%. Ini menandakan ibu mengalami anemia ringan. Oleh karena itu ibu memiliki dua point yang menyebabkan klien masuk dalam kategori risiko tinggi, diantaranya usia ibu lebih dari 35 tahun dan mengalami anemia ringan. Berdasarkan skor pudji rohyati usia lebih dari 35 tahun memiliki skor 4 dan anemia memiliki skor 4 .

Pada kasus ini, bu sebelumnya menggunakan kontrasepsi suntik, kontrasepsi ini tentu tidak tepat untuk ibu dengan usia diatas 35 tahun sehingga risiko terjadi kehamilan itu tinggi. Kehamilan di usia berisiko ini sebenarnya dapat dicegah yaitu dengan menggunakan alat kontrasepsi yang berprinsip pada pola KB rasional. Hal ini sesuai dengan teori dari Hartono (2010) dalam penelitian Gustina 2020 yaitu dengan berpola pada 3 fase yaitu fase me-nunda/mencegah kehamilan apabila usia ibu <20 tahun, fase menjarangkan kehamilan bagi PUS dengan usia ibu 20-35 tahun (periode di mana usia ibu antara 2030/35 tahun merupakan periode usia paling baik untuk melahirkan), fase menghentikan /mengakhiri kehamilan /kesuburan pada periode umur 


\section{Prosiding Seminar Nasional Kesehatan \\ Lembaga Penelitian dan Pengabdian Masyarakat Universitas Muhammadiyah Pekajangan Pekalongan}

ibu >30 tahun, terutama di atas 35 tahun. Oleh karena itu penulis memberikan asuhan mengenai kehamilan dengan risiko tinggi agar ibu mengerti mengenai risiko yang mungkin terjadi pada ibu dan dapat dicegah dengan melakukan pemeriksaan antenatal secara rutin.

Pada kasus klien tersebut mengalami perubahan psikologis yaitu merasakan cemas dalam menghadapi persalinan, hal ini sesuai dengan penelitian dari Rianda (2016) dalam penelitian damayanti tahun 2019 bahwa ibu hamil trimester III mengalami kecemasan dalam menghadapi persalinan. Pada trimester III sampai saat proses persalinan merupakan masa penantian dengan kewaspadaan. Pada kasus $\mathrm{Ny}$. $\mathrm{N}$ dapat dievaluasi bahwa penulis memberikan asuhan berupa dukungan emosional menghadapi persalinan Hal ini sesuai dengan Standar Kompetensi Bidan berdasarkan Permenkes RI Nomor 28 tahun 2017 kompetensi ke-3 bahwa bidan memberikan asuhan antenatal bermutu tinggi untuk mengoptimalkan kesehatan selama kehamilan yang meliputi, deteksi dini, pengobatan atau rujukan dari komplikasi tertentu dengan memiliki pengetahuan dasar mengenai perkembangan psikologis yang normal dalam kehamilan dan dampak kehamilan terhadap keluarga, bidan memiliki keterampilan dasar memberikan bimbingan dan persiapan persalinan, kelahiran dan menjadi orang tua.

Pada kasus Ny. N pada setiap kunjungan ibu selalu mengeluhkan sering buang air kecil. Hal ini merupakan ketidaknyamanan yang sering dialami ibu hmil pada trimester III. Berdasarkan teori yang dikemukakan oleh Dewi \& Sunarsih, 2012 dalam penelitian podungge 2020, ketidaknyamanan sering buang air kecil yang dirasakan oleh ibu hamil trimester III secara fisiologis disebabkan karena ginjal bekerja lebih berat dari biasanya, karena organ tersebut harus menyaring volume darah lebih banyak dibanding sebelum hamil. Proses penyaringan tersebut kemudian menghasilkan lebih banyak urine. Kemudian janin dan plasenta yang membesar juga memberikan tekanan pada kandung kemih, sehingga menjadikan ibu hamil harus sering ke kamar kecil untuk buang air kecil. Gangguan tidur yang dirasakan oleh ibu dikarenakan sering terbangun untuk buang air kecil terutama pada malam hari.

Oleh karena itu penulis memberikan asuhan untuk memperbanyak minum di siang hari dan mengurangi minum dimalam hari agar tidak mengganggu istirahat ibu.

Pada kunjungan ke dua ibu mengalami cemas karena anaknya yang sakit, anaknya menjadi rewel sehingga mengganggu pikiran ibu dan juga istirahat ibu menjadi kurang. Oleh karena itu penulis memberikan asuhan mengenai dukungan dan motivasi kebada ibu agar tidak merasa cemas lagi ibu bisa bergantian dengan suami atau anggota keluarga yang lain dalam menjaga anaknya sehingga kebutuhan istirahat ibu tetap terpenuhi serta membawa anaknya periksa ke tenaga kesehatan untuk mendapatkan penanganan lebih lanjut.

Pada kunjungan ke 4 tanggal 9 januari 2021 dilakukan pemeriksaan Hb ulang dan didapatkan ibu mengalami anemia ringan. Hal ini mungkin dikarenakan ibu sempat berhenti mengkonsumsi tablet tambah darah karena habis serta asupan makanan berzat besi masih kurang. Oleh karena itu penulis memberikan asuhan untuk mengkonsumsi tablet tambah darah secara rutin lagi dan memperbanyak makanan yang mengandung zat besi. 


\section{Prosiding Seminar Nasional Kesehatan \\ Lembaga Penelitian dan Pengabdian Masyarakat Universitas Muhammadiyah Pekajangan Pekalongan

Faktor usia ibu yang lebih dari 35 tahun juga lebih berisiko untuk mengalami anemia. Hal ini sejalan dengan penelitian Sjahriani tahun 2019 bahwa ada hubungan antara usia ibu dengan kejadian anemia pada ibu hamil yang di sebabkan oleh faktor fisik dan psikis ibu. Dari data hasil penelitian yang didapat dari responden dalam penelitian tersebut kejadian anemia pada usia berisiko terdapat 44,9\%.

Dibuktikan pula pada penelitian Fatkhiyah tahun 2018 berdasarkan hasil uji chi squere diketahui bahwa gterdapat hubungan usia ibu dengan kejadian anemia $(p=0,006)$ dengan nilai old ratio $1,55-2,43$. Dari hasil penelitian didapatkan bahwa mayoritas responden dalam penelitian ini yaitu ibu hamil pada usia 20 tahun dan 35 tahun masing-masing sebanyak 4 orang. Hal ini menunjukan bahwa umur $<20$ tahun secara biologis dan psikologisnya belum optimal dengan emosi yang cenderung labil, kesiapan psikologis yang belum matang. Sedangkan pada umur $>35$ tahun mempunyai risiko untuk hamil Karena pada usia ini, alat reproduksi ibu sudah mulai menurun dan kekuatan untuk mengejan saat melahirkan sudah berkurang sehingga anemia pun terjadi pada saat ibu hamil umur $>35$ tahun. Jadi semakin tua usia ibu untuk hamil akan cenderung dapat mengalami anemia.

Risiko tinggi kehamilan dalam kasus ini bersifat dinamis, karena ibu hamil yang pada mulanya normal namun secara tiba-tiba dapat menjadi berisiko tinggi. Deteksi awal pada kehamilan harus dilakukan karena dapat dijadikan sebagai salah satu upaya untuk mencegah kehamilan dengan risiko tinggi pada ibu hamil. Risiko tinggi pada kehamilan merupakan keadaan kehamilan yang menyimpang dari keadaan normal, yang secara langsung dapat menyebabkan kesakitan dan kematian ibu maupun kematian bayi (Andriyani, 2020). Oleh karena itu dalam setiap kunjungan yang dilakukan diberikan asuhan untuk periksa rutin ke tenaga kesehatan sebagai upaya deteksi dini untuk mencegah komplikasi.

\section{Kesimpulan}

Setelah Setelah dilakukan studi kasus ini dapat disimpulkan bahwa pada ibu hamil dengan resiko tinggi sebaiknya dilakukan asuhan untuk rutin memeriksakan diri ketenaga kesehatan baik dokter maupun bidan sebagai upaya deteksi dini untuk mencegah timbulnya komplikasi sesuai kebutuhan dan kewenangan selain itu ibu tetap diberi asuhan mengenai keluhan yang dirasakan ibu untuk mengurangi kecemasan ibu hamil.

Sebaiknya bidan ataupun pelayanan kesehatan primer dalam pengelolaan kasus dipertahankan dan dapat ditingkatkan sesuai standar pelayanan dan kompetensi bidan serta menambah sumber daya manusia sarana dan prasarana serta memperbarui ilmu mengenai penanganan kasus dan deteksi dini untuk mencegah terjadinya kegawatdaruratan terutama pada ibu hamil dengan risiko tinggi.

\section{Referensi}

Agrippina, Selly Yunia, Historyati, Dyah, Prihartanti, Niken Grah, 2017, 'Asuhan Kebidanan Pada Ibu Hamil Trimester Iii Di Bpm Anisah Desa Denanyar Kecamatan Jombang Kabupaten Jombang', Jurnal Ilmiah Kebidanan, Vol 3, No 2 


\section{Prosiding Seminar Nasional Kesehatan \\ Lembaga Penelitian dan Pengabdian Masyarakat Universitas Muhammadiyah Pekajangan Pekalongan}

Andriyani, Rika.2020. Asuhan Kebidanan Pada Ibu Hamil Dengan Risiko Tinggi Di Pmb Putri Asih Kota Pekanbaru Tahun 2019. vol.11.Pekanbaru. Jurnal Komunikasi Kesehatan

Astriana, Willy, 2017, 'Kejadian Anemia Pada Ibu Hamil Ditinjau Dari Paritas Dan Usia', Jurnal IImu Kesehatan, Vol. 2, No.2, Hal123-130

Damayanti, I 2019, 'Asuhan Kebidanan pada ibu hamil dengan Ketidaknyamanan Sering BAK', Ensiklopedia of Jurnal, Vol.1, No.4, Edisi 2 Juli 2019

Fatkhiyah, Natiqotul.2018. Faktor Risiko Kejadian Anemia Pada Ibu Hamil (Studi Di Wilayah Kerja Puskesmas Slawi Kabupaten Tegal.Vol.2.Tegal:Indonesia Jurnal Kebidanan

Gustina, Irwanti, 2020, 'Penyuluhan Kesehatan Pada Ibu Hamil Tentang Mempersiapkan Kehamilan Dan Persalinan Ditengah Pandemic Covid-19' Jurnal Pengabdian Masyarakat, vol. 1, no. 1.

Marcelya, Shella.2018. Faktor Pengaruh Risiko Kehamilan "4t" Pada Ibu Hamil.Vol.1.Semarang.Indonesian Jurnal Of Midwife

Podungge, Yusni.2020. Asuhan kebidanan komprehensif.Vol.2.Gorontalo Jambura Health and Sport Journal

Sjahriani, Tessa, Faridah, Vera.2019. Faktor-Faktor Yang Berhubungan Dengan Kejadian Anemia Pada Ibu Hamil. Jurnal Kebinan vol. 5.

Susiana, Sali.2019, 'Angka Kematian Ibu : Faktor Penyebab Dan Penangananya'pusat Penelitian Bidang Keahlian DPR RI, vol. 11, no. 24, hal 13-18

Sutarmi, Zakir, Mardiana.2013. Hubungan Usia Ibu Dengan Komplikasi Kehamilan Pada Primigravida.vol.4 jurnal Ilmiah keperawatan. 